This item was submitted to Loughborough's Research Repository by the author.

Items in Figshare are protected by copyright, with all rights reserved, unless otherwise indicated.

\title{
Executive bonus and firm performance in the UK
}

PLEASE CITE THE PUBLISHED VERSION

PUBLISHER

(c) Loughborough University

LICENCE

CC BY-NC-ND 4.0

\section{REPOSITORY RECORD}

Bruce, Alistair, Rodion Skovoroda, Jay Fattorusso, and Trevor Buck. 2019. "Executive Bonus and Firm Performance in the UK". figshare. https://hdl.handle.net/2134/2084. 
This item was submitted to Loughborough's Institutional Repository by the author and is made available under the following Creative Commons Licence conditions.

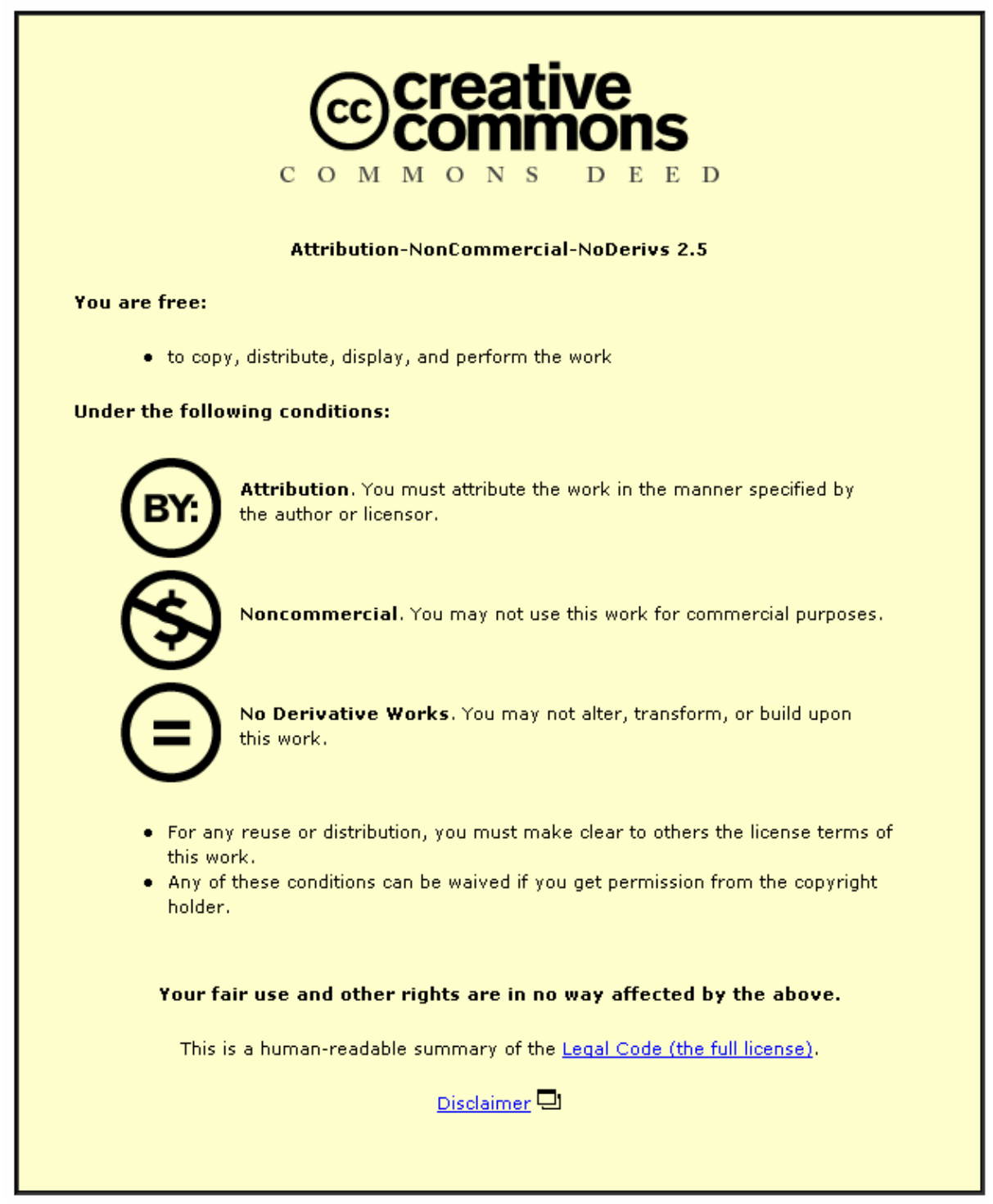

For the full text of this licence, please go to: http://creativecommons.org/licenses/by-nc-nd/2.5/ 


\section{Executive Bonus and Firm Performance in the UK}

by Alistair Bruce, Rodion Skovoroda, Jay Fattorusso and Trevor Buck

\section{Business School}

Occasional Papers Series

Paper 2005: 3

ISBN 1859011950 


\title{
Executive Bonus and Firm Performance in the UK
}

\author{
by
}

Alistair Bruce, Rodion Skovoroda, Jay Fattorusso and Trevor Buck

Business School Occasional Papers Series

Paper 2005: 3

ISBN 1859011952

July 2005

THIS PAPER IS CIRCULATED FOR DISCUSSION PURPOSES AND ITS

CONTENTS SHOULD BE CONSIDERED PRELIMINARY AND CONFIDENTIAL. NO REFERENCE TO MATERIAL CONTAINED HEREIN MAY BE MADE WITHOUT THE CONSENT OF THE AUTHORS. 


\title{
EXECUTIVE BONUS AND FIRM PERFORMANCE IN THE UK
}

\author{
Alistair BRUCE \\ Nottingham University Business School \\ Jubilee Campus \\ Nottingham NG8 1BB \\ Alistair.Bruce@nott.ac.uk \\ Rodion SKOVORODA \\ Loughborough University Business School \\ Loughborough LE11 3TU \\ r.skovoroda@lboro.ac.uk \\ Jay FATTORUSSO \\ Loughborough University Business School \\ Loughborough LE11 3TU \\ j.fattorusso@lboro.ac.uk \\ Trevor BUCK \\ Loughborough University Business School \\ Loughborough LE11 3TU \\ t.w.buck@lboro.ac.uk
}

Thanks to the ESRC for their financial support for this work. 


\section{Biographical Note}

Professor Alistair Bruce is Director of the Nottingham University Business School", with recent publications in Applied Economics, Journal of Management Studies, and the Economic Journal. He is part of the team researching Executive Pay and Firm Performance, with support of $£ 212,000$ from the ESRC.

Trevor Buck is Professor of International Business at Loughborough University Business School, leader of the ESRC project on executive pay (see above). Rodion Skovoroda is ESRC Research Fellow at Loughborough on the project and Jay Fattorusso a full-time PhD student. 


\begin{abstract}
Annual bonus is a controversial but under-researched dimension of executive pay. Bonus packages have the chameleon-like ability to suit CEOs, shareholders or both. In other words, they may be consistent with executive power theory and the notion of "fat cats" and/or agency theory. As with many other components of executive pay, the "devil may be in the detail", and trends in the particular architecture of schemes may prove to be at least as important as aggregate relationships.
\end{abstract}

This paper presents new results on executive bonuses in the UK's large firms. The agency perspective on the role of executive bonus is supported by the significant, aggregate, positive relation between CEO bonus pay and a firm's financial performance. Results for the UK during a unique period of slack capital markets produces measures of bonus pay-performance responsiveness that are broadly in line with earlier studies. Transparency in bonus schemes (in the sense of simplicity in targets) is positively associated with firm performance, as agency theorists would predict. This all suggests that CEO bonuses offer a strong and consistent basis for the alignment of principals' and agents' interests.

However, this apparent support for agency theory should be viewed with caution. While bonus simplicity is associated positively with performance, it would appear that detailed bonus scheme characteristics are generally insensitive to this relationship. Bonus schemes in the UK are becoming more complex in terms of the use of multiple targets. There appears to be a trend towards the abandonment of simple schemes with unpublished targets, in favour of schemes with more targets, and unpublished ones at that.

Of course "Individual Performance Evaluation”, where Boards have some discretion over the amount of bonus paid against unpublished or undisclosed targets, may succeed in theory, especially where the nature of the business makes it advisable to keep CEO targets confidential. Nevertheless, the implication of this paper is that, on balance, transparency in the form of simplicity (and associated published targets) is positively associated with firm performance. 
The design of reward packages for main board directors is a crucial strategic decision for firms, that impinges on the quality of all other strategic decisions. The aim of this paper is to investigate and assess the implications of current practice among large UK companies in relation to the award of annual bonuses to senior executives. There is a long and well documented tradition of empirical enquiry into many aspects of executive remuneration, but much of this has focused on the relationship between the total pay packages of senior executives and firm performance, plus a range of firm level variables such as size and governance characteristics ${ }^{1}$.

A subsidiary strand of research, starting with Jensen and Murphy ${ }^{2}$, has sought to isolate the effect of particular elements of pay on this type of relationship. In this context, it is perhaps surprising that one of the most established elements of executive reward, the annual bonus, has received very limited attention. This paper seeks to address this omission by examining contemporary practice in relation to the rationale for bonus awards, the size of awards in absolute and relative terms, the impact of bonus on the pay-performance relationship and the transparency of practice in relation to bonus payments. This research offers a timely insight into bonus practices against a backdrop of considerable contemporary disquiet within policymaking and stakeholder communities in the UK regarding the terms of senior executives' contracts and their role in influencing the quality of corporate governance.

Although this paper focuses on short term (annual) executive bonus, repeat doses of bonus have long term implications, and the following analysis to a large extent mirrors the treatment of long term incentives in the literature. It is organised as 
follows. Section 1 offers a selective overview of the executive compensation literature. Section 2 outlines some general features of the architecture of executive remuneration in modern UK firms, accounts for the relative absence of bonus-related research and identifies specific research questions. Section 3 derives hypotheses concerning the links between executive bonus pay and firm performance, Section 4 describes the methodology and data which offer insights into current UK practice, and Section 5 offers an interpretation of the results of the application of this methodology to the data. Some concluding remarks and suggestions for extensions to this area of research follow.

\section{Previous Studies}

There is a long tradition of empirical investigation into aspects of executive remuneration, particularly in the USA. At the risk of oversimplification, much of the earlier material in this area sought to explore the relationship between total executive pay, variously measured, and a range of firm-level (normally financial) performance variables, such as turnover, market and/or accounting performance. The motivation

for this line of work had its origins in Baumol's contribution in $1959^{3}$, which inspired a generation of researchers to probe the determinants of executive pay. The focus of analysis in early studies was typically on either rewards to the Chief Executive Officer (CEO) or to the board as a whole, with the principal components of remuneration under scrutiny at first being base salary plus annual bonus. This focus reflected the comparatively simple composition of reward packages which invariably applied in the USA, and more especially the UK, prior to the 1980s. Later studies sought to incorporate long term incentives such as share options, as they became established elements of executive pay. 
The general consensus ${ }^{4}$ emerging from this body of work in the USA was that there are stronger identifiable correlations between pay and size-related variables, in particular turnover, than between pay and performance. (Details of these payperformance studies are presented later.) This lent weight to Baumol's earlier conclusions $^{5}$ and raised the possibility that the design of executive remuneration was perhaps influenced by managerialist factors, rather than by efficiency-motivated attempts to promote executive-shareholder (principal-agent) interest alignment through stronger pay-performance sensitivities. Jensen and Murphy ${ }^{6}$ concluded that (p227) "We believe our results are inconsistent with the implications of formal agency models or optimal contracting. The empirical relation between the pay of top-level executives and firm performance, while positive and significant, is small for an occupation where incentive pay is expected to play an important role.”

\section{Executive Pay in the UK}

Empirical inquiry into executive pay in the UK in the last two decades has had to embrace a number of local innovations in remuneration practice. Principally, this has involved assembling more comprehensive pay measures which incorporate stockbased compensation, that is more recently-developed, long-term, performancecontingent pay elements, notably executive share options (ESOs) and, (specific to the UK), long-term incentive plans (LTIPs), which are performance-conditional awards of cash or shares (but not options).

Interest in this area has been fuelled by a vigorous contemporary debate in the UK regarding, on the one hand, allegedly high absolute levels of executive reward and, on 
the other, a weak link between pay, performance and shareholder return. Central to this debate has been a concern that pay innovations, such as ESOs, offer executives a near riskless, and potentially very substantial, increase in total remuneration, irrespective of corporate performance, particularly during `bull’ markets. The wider context for this body of enquiry has been a growing anxiety regarding the state of the ‘Anglo-American’ model of corporate governance in the light of a series of high profile and sometimes catastrophic failures of governance. In the UK, this anxiety has been reflected in a series of influential reports on aspects of corporate governance, the Cadbury (1992), Greenbury (1995), Hampel (1998) and Turnbull (1999) Reports, a tradition which has been sustained more recently by the Smith (2003) and Higgs (2003) Reports ${ }^{7}$.

As with executive pay research in the USA, empirical studies in the UK have produced mixed results, but the importance of firm size, rather than performance, has again been a dominant feature ${ }^{8}$. Again in line with

\section{INSERT TABLE 1 NEAR HERE}

the US literature, UK studies have adopted the same two important metrics for judging the responsiveness of pay to performance, (see footnote to Table 1). First, performance-pay sensitivity measures the absolute response of executive pay to changes in shareholder value, though the relative dimensions of the variables compromise the usefulness of this measure. Executive pay, even by American standards, and particularly changes in pay, are extremely small in relation to shareholder value, which is often measured in many billions of dollars for large firms. Hence, Jensen and Murphy ${ }^{9}$ estimated a tiny median sensitivity of 0.0135 for cash 
pay. This denotes that $\$ 1,000$ of additional shareholder value is associated with 1.35 cents of extra pay.

Such absolute measures may appear to trivialise pay-performance relations. Since this study addresses executive bonus, which is itself only a small part of executive pay compared with long term components such as ESOs, a second, relative measure of responsiveness seems to be more illuminating. Therefore, the performance-pay elasticity is employed, which relates percentage changes in pay to percentage changes in shareholder value.

Prior to this study, estimates of both pay sensitivity and elasticity (see Table 1) for the UK produced results rather lower than those observed in the USA. Thus, for salary, bonus and ESOs, Conyon and Murphy ${ }^{10}$ calculate a sensitivity of 2.33 compared with 6.00 for the USA ${ }^{11}$, whilst elasticity in the UK $(0.121)$ bore a similar relation to elasticity in the USA (0.39) in these studies.

Ironically, when comprehensive valuations of LTIPs were estimated for the $\mathrm{UK}^{12}$, it was found that LTIPs (embodying performance conditions that were supposed to increase sensitivity) were associated with the opposite effect, with sensitivity as low as 1.55. Such an outcome is not inconsistent with self-serving executives designing soft LTIP performance conditions for themselves that weakened the performance-pay link.

A clue to this phenomenon is provided by the title of the DTI Consultative Document "Reward for Failure?"13. There is some suggestion here that the opaqueness of LTIP 
schemes, in terms of their complexity and the lack of an easily observable link between share price and rewards (as is the case with ESOs) has weakened their link with performance. Many LTIPs reward average performance ${ }^{14}$ and often rely upon comparator groups of companies as yardsticks. Evidence from the USA ${ }^{15}$ has certainly demonstrated that executives there have manipulated the composition of such groups, apparently to make their firm's performance look better. Such managerial discretion could be interpreted as being part of the general issue of “camouflage” ${ }^{\text {, }}$, discussed later in respect to executive bonuses. Whether or not the detail of scheme design represents a wilful attempt to frustrate effective shareholder scrutiny of pay arrangements, it may be argued that scheme complexity fails to offer a clear incentive to eligible executives in the sense that incentives need to be transparent in order to be effective.

The degree of attention afforded to the scrutiny of such stock-based compensation, and ESOs in particular, in the last twenty years is in stark contrast to that given to the scrutiny of annual bonuses. It is a contention of this paper that this unevenness should be addressed, particularly as in recent times UK companies have found stock-based compensation a less useful and attractive tool for rewarding executives, given the unfavourable performance of equity markets. Now, there is at least a suspicion that they may be turning instead to the annual bonus as a source of softer rewards.

Bonuses were, of course, an element of UK pay practice long before recent anxieties regarding corporate governance arrangements in UK companies became an issue, but equally there has often been a tolerance of bonuses as a less transparent form of reward than long term incentives. It has been argued, for example, that it is entirely 
appropriate for annual bonus to be based on individual, confidential terms that are related to measures of internal performance at an individual, divisional or company level. For example, “Individual Performance Evaluation” is fashionable in the USA, where some discretion is left to the Board over the amount of bonus paid. This applies to around $42 \%$ of the CEO bonuses of large firms in the USA ${ }^{17}$.

Probably as a result of arguments citing the sensitive commercial nature of bonus targets, the regulation of bonuses has been relatively weak in the UK. Thus, the 2003 Combined Code ${ }^{18}$ bundles annual bonuses together with other performance-related forms of pay, and states that all incentives should be subject to "challenging performance conditions", and "performance conditions should be relevant, stretching and designed to enhance the business”. However, no detailed regulations exist specifically for bonus performance conditions.

Whatever the relative merits of undisclosed targets or bonus targets which are transparent to shareholders, however, an agency perspective would suggest that any changes to bonus schemes in terms of the form of payment (cash or shares) or more transparent performance targets should be expected to raise pay-performance sensitivity without necessarily raising pay-outs. Greater transparency may be expected to expose executives to more shareholder supervision, providing another incentive for CEOs to act in the interest of shareholders, again raising pay-performance sensitivity.

Clearly, however, this relative lack of regulation and transparency offers at least the opportunity for levels of individual reward that might otherwise attract concern or criticism and is this also forms part of the case for more detailed academic enquiry. In 
line with the literature on long-term incentives, the focus here is on any links between executive bonus payments and firm performance.

\section{Hypotheses}

In developing hypotheses that might offer an insight into the contemporary impact of bonus payments to UK executives, it is instructive to consider alternative theoretical perspectives on executive pay which give rise to expectations of distinct empirical outcomes. The agency perspective ${ }^{19}$, otherwise known as the arm's-length contracting approach $^{20}$ is dominant. It underpins the analysis of governance in general and executive remuneration in particular, and sees remuneration design as part of the wider governance landscape, in terms of its potential to align the conflicting objectives of principals and agents, shareholders and executives. To the extent that alignment is realised, both individual components of pay, and aggregate pay, might be expected to be positively correlated to firm-level performance measures such as total shareholder return ${ }^{21}$.

However, a rather different perspective assigns a more significant role to managerial power as an influence on the design of executive pay. Here, the exercise of power would be evidenced by managerial rent extraction at the expense of principals, resulting in weak alignment between pay and firm performance and by levels of executive reward which are resilient to periods of poor corporate performance ${ }^{22}$.

It should be noted that, whilst these competing agency and managerial power perspectives are frequently characterised as representing quite distinct views on corporate governance, agency theorists would tend to view managerial power as no 
more than a special case of the agency relation, which is likely to apply where governance institutions and processes are weak. For the purposes of this paper, however, whether or not the managerial power perspective is seen as a variant of agency is not an issue.

In terms of aggregate bonus payments and performance, the agency perspective forms the basis of our first hypothesis, while a managerial power approach would suggest its negation:

H1: There is a significant positive relationship between levels of bonus paid to executives and company performance.

This hypothesis mirrors similar hypotheses proposed in the general literature on executive pay (including share options). It may be tested in terms of changes in aggregate reward and firm performance, but it focuses only on the overall financial relationship between bonus and corporate performance. The literature in relation to stock-based compensation would argue, however, that it is just as important to investigate the relationships between the micro-institutional features of bonus schemes and firm performance, as well as aggregate relations. To the extent that the importance of bonus as a pay component is increasing, in the context of ineffective stock-based compensation during flat periods in equity markets, detailed aspects of bonus arrangements become a natural focus for scrutiny by academic researchers as well as shareholder groups and the media. In particular, there is a perception that scheme award criteria may be motivated principally by executive power and a desire to achieve higher levels of effectively guaranteed payments. 
It was observed earlier that the conditions (or targets) which determine levels of bonus payment are diverse, individual and inconsistent in transparency across companies. Whilst this presents some difficulties for comparative analysis, it is possible to develop a classification which discriminates between, on the one hand, those companies that rely on transparent or external criteria and, on the other, those that employ largely opaque (unpublished and internal) criteria for bonus award, as well as between those that use single and those employing multiple targets.

Indeed, Bebchuk and Fried ${ }^{23}$ use their managerial power perspective to argue that executives use “camouflage”, by “dressing, packaging and hiding” additional rent extraction, thus obscuring higher pay-outs and making bonuses seem more performance-based than they actually are. In relation to executive bonus, three dimensions seem relevant to this concept of camouflage. Transparency (the negation of camouflage) could be associated with (a) simple targets (with one instead of multiple performance conditions), (b) published targets and (c) cash payments (as opposed to shares and other instruments further from cash).

Agency theorists would predict that transparent bonus conditions (i.e. cash-only rewards, simple and published targets) would encourage executives to act like shareholders. Similarly, managerial power theorists would emphasise that opaque schemes (non-cash, with multiple and unpublished targets) represent opportunities for executives to conceal rent-extraction at the expense of shareholders. 
Both sets of theory would imply that bonus scheme characteristics of transparency/camouflage would be complementary. In other words, executives intent on camouflage would not use single targets based on published performance indicators. Instead they would use a multiplicity of unpublished targets.

Thus, we propose:

H2: Bonus scheme characteristics associated with bonus transparency (and camouflage) are predicted to occur simultaneously in actual executive bonus schemes.

From the power and agency perspectives, excess rents associated with guaranteed income schemes camouflaged as bonus schemes (without transparency) are unlikely to provide executives with the incentives needed to raise firm performance. Thus:

H3: Transparency in bonus schemes (however measured) will be negatively associated with bonus pay-outs.

\section{Data and Methodology}

Data on CEO rewards, firm performance in terms of shareholders' return and control variables (number of employees, industry dummy and American or otherwise nationality of CEOs) were collected from the annual reports of FTSE 350 companies (minus investment or unit trusts) for financial years 2002 and 2003. This left 299 firms, yielding a panel of 257 firms that had executive bonus schemes for each year. Of these 257, 119 reported some change in scheme between 2002 and 2003. 
This two-year panel of data enabled two cross-section analyses to be employed. A reliable measure of performance-bonus sensitivity requires estimation of the average performance-bonus relationship across two moments in time.

Bonus schemes were classified according to the types of targets used, see Table 2.

INSERT TABLE 2 NEAR HERE

For example, the most transparent schemes are based on share price alone (ET), or on some published variable (e.g. net profit or total sales) that may be verified from annual reports (called published internal target, PIT). Table 2 shows that there were 85 cases in 2002/03 of firms with publicly disclosed targets. Less transparent schemes used unpublished internal targets (UIT, 77 firms) and even, in 22 cases, completely undisclosed targets, presumably for reasons of commercial secrecy. All other cases involved combinations of published and unpublished targets.

For performance relations (H1 and H3), GLS in STATA was used to estimate the following equation:

$$
\log \left(1+\frac{\text { Bonus }}{\text { Salary }}\right)_{i, t}=\beta_{0}+\beta_{C} x_{i, 1}+\beta_{L}\left(x_{i, t}-x_{i, 1}\right)+u_{i}+\varepsilon_{i . t}
$$

for observations $t=1,2$ on firms $i=1, \ldots, 257$ (514 cases overall). The vector $x_{i, t}$ consisted of values of explanatory factors for firm $i$ in year $t$. It included:

1) Firm performance indicators: EPS, TSR and Log of number of employees.

2) Bonus design factors:

a) If bonus is paid in cash only, CASH dummy

b) type of target (ET, PIT, UIT or undisclosed target) see above. UIT was used as a base or reference dummy. 
c) Only one performance target (SIMPLE)

3) Control variables:

a) American nationality or other foreign nationality of CEO

b) Sector dummy for finance sector, FINANCE

In addition to these regressions concerning firm performance and executive bonus, the database was used to produce descriptive results that cast light on $\mathrm{H} 2$.

\section{Results}

Table 3 describes features of the balanced sample ( $n=257)$ for 2001/02 and 2002/03.

\section{INSERT TABLE 3 NEAR HERE}

It is clear that average (mean) executive bonus is no longer a trivial component of total cash pay, representing $61.0 \%$ of salary in 2001/02, rising to $67.2 \%$ in 2002/03. This is consistent with a new emphasis on annual bonus during a period of relatively static stock market prices and tight regulation of long term incentives.

\section{INSERT TABLE 4 NEAR HERE}

Table 4 shows the main regression results for the CEOs of 257 UK firms, 2001/02 and 2002/03. The results of the two cross-section regressions are discussed in relation to H1 and H3, but first we address the control variables.

Firms in the finance sector clearly show a tendency towards higher cash pay, after allowing for performance. Similarly, firms with non-British CEOs seem to offer a cash pay premium, but only in our second year. Unusually, firm size is insignificant throughout, and this contrasts with its significance in all earlier studies ${ }^{24}$. However, 
these studies addressed total pay (including option valuations) or cash pay (salary plus bonus) and no previous study focused exclusively on bonus. It would appear that bonus is one element of CEO pay which is not rigidly linked to firm size, offering more potential for influence from performance. (In this study, the transformation of the bonus variable employed eliminates the influence of size on bonus pay.)

Generally, the regressions provide consistent support for H1, the influence of firm performance and the agency theory that underpins it. Both measures of firm performance (EPS and TSR) are shown to be positively and significantly associated with bonus pay. In order to compare directly the responsiveness of bonus pay to the results for other countries and periods cited in Table 1, the coefficients on TSR in Table 4 were converted into sensitivities and elasticities (see footnotes to Table 1). Given the magnitude of shareholder value (with the median firm’s market capitalisation of $£ 1.446$ billion in 2002/03) and CEO pay, it has been observed that sensitivities (the absolute increase in CEO pay associated with a $£ 1,000$ increase in shareholder value) are bound to be low. In the case of this study, a £1,000 increase in shareholder value is associated with a median 2.12 pence increase in CEO pay, which yields a quite low pay-performance sensitivity of 0.0212 . This corresponds with the 0.0135 sensitivity calculated by Jensen and Murphy (1990) for salary and bonus, see Table 1.

As noted above, these quite trivial sensitivities (as a result of the shareholder value and executive bonus magnitudes) suggest that a relative rather than an absolute measure of responsiveness may be more enlightening. Pay-performance elasticities were therefore calculated, representing the percentage change in CEO pay associated 
with a percentage change in shareholder value. Over the two years, a $10 \%$ change in TSR was associated with a $2.19 \%$ increase in bonus, i.e. an elasticity of 0.219 . It can be seen from Table 1 that this is almost exactly the same result as the 0.22 calculated for cash pay in the USA, 1980-94 by Hall and Liebman ${ }^{25}$, and very close to the 0.26 estimated by Conyon and Benito (1999) for the UK, 1990-96.

This close correspondence of pay-performance elasticities (and sensitivities) for cash pay across different time periods and countries offers strong support for $\mathrm{H} 1$ and the agency perspective. However, a consideration of $\mathrm{H} 2$ and other hypotheses, when the detailed structure of executive bonus schemes is examined, is less supportive of agency theory.

Leaving aside $\mathrm{H} 2$ for the moment, $\mathrm{H} 3$ predicted that different dimensions of bonus scheme transparency (simplicity, published targets and cash rewards) would be associated with more shareholder control and lower levels of absolute pay. However, the particular type of target applied (PIT, ET or UIT) was found to have no significant association with the bonus variable, and cash pay only has the expected association (5\% significant) for the second year, 2002-03. Nevertheless, target simplicity is negatively and significantly associated with bonus pay for both years, with simple targets being associated with lower pay-outs. On average over the two years, simple targets are associated with 10-11\% lower cash pay for CEOs. Whilst such limited support for H3 would appear to endorse, to a degree, the agency view, a consideration of $\mathrm{H} 2$ provides new insights into executive bonus pay, and raises doubts about the efficacy of agency theory in the long term. 
The relations between the characteristics of bonus schemes are complex, but the picture emerges of an increasingly polarisation in forms of bonus package.

\section{INSERT TABLE 5 NEAR HERE}

For example, Table 5 shows that in 2001/02, 81 CEOs had a single performance target, and that in 57 of these cases, the single target was a published one. As the number of targets increases, they are less likely to be published.

By 2002/03, 19 firms had left the single target category, although ten of these 19 had unpublished targets previously. Of the seven firms which reduced the number of targets employed to one, five had a published target. This emphasises the polarisation, with simple (one target) schemes tending to use published conditions. In other words, two bonus characteristics (simplicity and published targets) associated with transparency (and less camouflage) are generally found to occur simultaneously in actual executive bonus schemes. To this extent, $\mathrm{H} 2$ is supported.

\section{Discussion and Conclusions}

Interpreting the significance of these results is not straightforward. An advocate of the agency perspective on the role of executive bonus would draw positive inferences from the significant relationship overall between CEO bonus pay and a firm’s financial performance. Results for the UK during a unique period of slack capital markets produce measures of bonus pay-performance responsiveness that are broadly in line with earlier studies. Furthermore, transparency in bonus schemes (in the sense of simplicity in targets) is positively associated with firm performance, as agency 
theorists would predict. This all suggests that CEO bonuses offer a strong and consistent basis for the alignment of principals’ and agents’ interests.

However, this apparent support for agency theory should be viewed with caution. While bonus simplicity is associated positively with performance, it would appear that detailed bonus scheme characteristics are generally insensitive to this relationship. Bonus schemes in the UK continue to become more complex in terms of the use of multiple targets. There appears to be a trend towards abandonment of simple schemes with unpublished targets in favour of schemes with more targets, and unpublished ones at that.

Of course “Individual Performance Evaluation”, where Boards have some discretion over the amount of bonus paid against unpublished or undisclosed targets, may succeed in theory, especially where the nature of the business makes it advisable to keep CEO targets confidential. Nevertheless, the implication of this paper is that, on balance, transparency in the form of simplicity (and associated published targets) generates the best results.

Future research may do well to focus on the long term tracking of bonus schemes against performance, particularly those that have been subjected to change. Of course, more than two cross-sections of data are needed for this task, and this is a substantial weakness of this paper. At the same time, another year of data requires about one researcher-year of data retrieval and inputting. 
CEO bonus still has the chameleon-like ability to suit CEOs, shareholders or both. As with many other components of executive pay, the "devil may be in the detail”, and trends in the particular architecture of schemes may prove to be at least as important as aggregate relationships. 


\section{NOTES}

${ }^{1}$ For recent surveys of this work, see Tosi, H.L., Werner, S., Katz, J.P. and GomezMejia, L.R. (2000) 'How Much Does Performance Matter? A Meta Analysis of CEO Pay Studies', Journal of Management, 26(2): 301-339; Core, J.E., Guay, W.R. and Larcker, D.F. (2003) 'Executive Compensation and Incentives: a Survey', Federal Reserve Bank of New York Economic Policy Review, 9(1): 27-50.

${ }^{2}$ Jensen, M.C. and Murphy, K.J. (1990) 'Performance Pay and Top Management Incentives’, Journal of Political Economy, 98(2): 225-264.

3 Baumol, W.J. (1959) Business Behaviour, Value and Growth (New York: MacMillan).

${ }^{4}$ Core et al., (2003), op. cit.

${ }^{5}$ Baumol, W.J. (1959), op. cit.

${ }^{6}$ Jensen, M.C. and Murphy, K.J. (1990), op. cit.

${ }^{7}$ Cadbury Committee (1992), The Financial Aspects of Corporate Governance, London: Gee Professional Publishing; Greenbury, R. (1995), Directors'

Remuneration. Report of a Study Group Chaired by Sir Richard Greenbury. London: Gee Publishing; Hampel, R. (1998), Committee on Corporate Governance. London: Gee Publishing; Turnbull, N. (1999), Internal Control: Guidance for Directors on the Combined Code, London: Institute of Chartered Accountants in England and Wales; Smith, R. (2003) Audit Committees: Combined Code Guidance. London: Financial Reporting Council; Higgs, D. (2003), Review of the Role and Effectiveness of NonExecutive Directors. London: Department of Trade and Industry.

${ }^{8}$ Benito, A and Conyon, M.J. (1999) 'The Governance of Directors’ Pay: Evidence from UK Companies’, Journal of Management and Governance, 3(2): 117-136.

${ }^{9}$ Jensen, M.C. and Murphy, K.J. (1990), op. cit.

${ }^{10}$ Conyon, M. J. and Murphy, K. (2000) 'The Prince and the Pauper? CEO Pay in the United States and United Kingdom’, Economic Journal, 110(647): 640-671.

${ }^{11}$ Hall, B.J. and Liebman, J.B. (1998) 'Are CEOs Really Paid like Bureaucrats?', Quarterly Journal of Economics, 111(3): 653-691.

12 Buck, T., Bruce, A., Main, B.G.M. and Udueni, H. (2003). 'Long Term Incentive Plans, Executive Pay and U.K. Company Performance', Journal of Management Studies, 40(7): 1709-1727.

13 Department of Trade and Industry (2003) 'Rewards for Failure: Directors' Remuneration - Contracts, Performance and Severance', DTI Consultative Document: London. 
${ }^{14}$ Pass (2003)

${ }^{15}$ Porac, J.F., Wade, J.B. \& Pollock, T.G. (1999) 'Industry Categorizations and the Politics of the Comparable Firm in CEO Compensation', Administrative Science Quarterly, 44(1): 112-144.

${ }^{16}$ Bebchuk, L.A. and Fried, J.M. (2004) Pay Without Performance: The Unfulfilled Promise of Executive Remuneration, Harvard University Press: Harvard.

17 Murphy, K. and Oyer, P. (2003) Discretion in executive incentive contracts, Marshall School of Business Working Paper, June 2003, University of Southern California, Los Angeles, http://www-rcf.usc.edu/ kjmurphy/publications.htm

${ }^{18}$ Combined Code (2003), London: Financial Reporting Council.

${ }^{19}$ e.g. Tosi, H.L. Jr and Gomez-Mejia, L.R. (1989) 'The Decoupling of CEO Pay and Performance: An Agency Theory Perspective', Administrative Science Quarterly, 34(3): 169-189; Murphy, K. (2002) 'Explaining Executive Compensation: Managerial Power vs. Perceived Cost of Stock Options’, University of Chicago Law Review, 69(3): 847-869; Core et al. (2003), op. cit.

${ }^{20}$ Bebchuk, L.A., Fried, J.M. and Walker, D.I. (2002) 'Managerial Power and Rent Extraction in the Design of Executive Compensation', University of Chicago Law Review, 69(4): 751-846.

${ }^{21}$ Tosi et al. (2000), op. cit.

${ }^{22}$ Bertrand, M. and Mullainathan, S. (2001) 'Are CEOs Rewarded for Luck? The Ones without Principals Are’, Quarterly Journal of Economics, 116(3): 901-932; Bebchuk et al. (2002), op. cit.; Bebchuk and Fried (2004), op. cit.

${ }^{23}$ Bebchuk and Fried (2004), op. cit., p67

${ }^{24}$ Tosi et al. (2000), op. cit.

${ }^{25}$ Hall and Liebman (1998), op. cit. 
TABLE 1: Estimates of Median Executive Pay-Performance Sensitivities and Elasticities Compared

\begin{tabular}{|c|c|c|c|}
\hline $\begin{array}{c}\text { Researcher(s) } \\
\text { (date) }\end{array}$ & $\begin{array}{c}\text { Country } \\
\text { (Years studied) }\end{array}$ & $\begin{array}{l}\text { Performance-Pay } \\
\text { Sensitivity }^{1}\end{array}$ & $\begin{array}{l}\text { Performance-Pay } \\
\text { Elasticity }^{2}\end{array}$ \\
\hline Jensen and Murphy & USA & & \\
\hline $\begin{array}{l}\text { (1990) (Salary and } \\
\text { bonus only) }\end{array}$ & (1974-1986) & 0.0135 & - \\
\hline Jensen and Murphy & USA & & \\
\hline (1990) & (1974-1986) & 3.25 & - \\
\hline Hall \& Liebman & USA & & \\
\hline $\begin{array}{l}\text { (1998) (Salary and } \\
\text { Bonus only) }\end{array}$ & $(1980-1994)$ & - & 0.22 \\
\hline Hall \& Liebman & USA & & \\
\hline (1998) & $(1980-1994)$ & 6.00 & 0.39 \\
\hline Benito \& Conyon & UK & & \\
\hline $\begin{array}{l}\text { (1999) (Salary and } \\
\text { Bonus only) }\end{array}$ & (1990-1996) & - & 0.26 \\
\hline Conyon \& Murphy & UK & & \\
\hline$(2000)$ & (1997) & 2.33 & 0.121 \\
\hline Buck et al. (2003) & $\begin{array}{l}\text { UK } \\
(1998)\end{array}$ & 1.55 & - \\
\hline $\begin{array}{l}\text { Current Study } \\
\text { (2005) (Bonus only) }\end{array}$ & $\begin{array}{c}\text { UK } \\
(2001 / 02,2002 / 03)\end{array}$ & 0.0212 & 0.219 \\
\hline
\end{tabular}

${ }^{1}$ Performance-Pay Sensitivity shows the absolute increment to pay associated with a 1,000 unit (e.g. $\$$ ) increase in shareholder value, so a sensitivity of 0.0135 (for salary and bonus, Jensen and Murphy, 1990) denotes that an additional $\$ 1,000$ of shareholder value is associated with a 1.35 cents of additional executive pay. It is calculated by regressing changes in executive pay on changes in shareholder value.

${ }^{2}$ Performance-Pay Elasticity shows the \% responsiveness of pay to a \% change in performance. For example, an elasticity of 0.10 denotes that a CEO associated with a $20 \%$ rate of return would be paid $1 \%$ more than a CEO associated with 10\% (Hall and Liebman, 1998, p 654). It is calculated by regressing the change in the log of executive pay on change in the log of shareholder value. 
TABLE 2: Performance Targets, 2002/03

Number of performance targets (2002-03)

Performance

target types

ET

ET \& PIT

ET \& PIT \&

UIT

ET \& UIT

PIT

PIT \& UIT

UIT

Undisclosed

Column total

$\begin{array}{rr}\text { N/A } & \mathbf{1} \\ 0 & 0 \\ 0 & 0 \\ & \\ 0 & 0 \\ 0 & 0 \\ 0 & 57 \\ 0 & 0 \\ 0 & 19 \\ 10 & 0 \\ \mathbf{1 0} & \mathbf{7 6}\end{array}$

2

2

Row

4 total

0

0

3

0

$0 \quad 0$

$\begin{array}{lll}4 & 0 & 7\end{array}$

0

(3)

6

9

7

$\begin{array}{llll}5 & 1 & 1 & 7\end{array}$

$\begin{array}{lllr}19 & 8 & 1 & 85\end{array}$

$\begin{array}{llll}47 & 48 & 20 & 115\end{array}$

$\begin{array}{llll}29 & 10 & 3 & 61\end{array}$

0

103

0
74

0
31

10

294 
TABLE 3 Mean/Median CEO Salary and Bonus, 257 FTSE350 firms.

$\begin{array}{cccc}\text { Year } & \begin{array}{c}\text { Average (median) } \\ \text { salary } \boldsymbol{E}\end{array} & \begin{array}{c}\text { Average (median) } \\ \text { bonus figure, } \boldsymbol{£}\end{array} & \begin{array}{c}\text { Average (median) } \\ \text { salary + bonus, } \boldsymbol{£}\end{array} \\ \mathbf{2 0 0 1 - 0 2} & 400,675 & 244,321 & 644,996 \\ & (356,000) & (130,000) & (496,000) \\ \mathbf{2 0 0 2 - 0 3} & 447,072 & 300,323 & 747,394 \\ \begin{array}{c}\text { Average } \\ \text { over two } \\ \text { years }\end{array} & (403000) & (170,500) & (569,000) \\ & 423,873 & 272,322 & 696,195 \\ & (385,500) & (139,500) & (529,500)\end{array}$

Note: median salary plus median bonus does not sum to median (salary + bonus) 
TABLE 4. CEO Annual Bonus and Firm Performance

\begin{tabular}{|c|c|c|c|c|c|c|}
\hline \multicolumn{4}{|c|}{ 2001-02 cross-sectional model } & \multicolumn{3}{|c|}{$2002-03$ cross-sectional model } \\
\hline & & Coef. & Robust Std. Err. & & Coef. & Robust Std. Err. \\
\hline \multirow{3}{*}{ 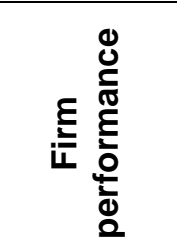 } & EPS & $0.001773(* \star)$ & 0.000562 & EPS & $0.001614\left(^{*}\right)$ & 0.000649 \\
\hline & TSR & $0.147541(* *)$ & 0.046713 & TSR & $0.097742\left(^{*}\right)$ & 0.041613 \\
\hline & Firm SIZE & -0.00428 & 0.012957 & Firm SIZE & 0.013472 & 0.012511 \\
\hline \multirow{6}{*}{ 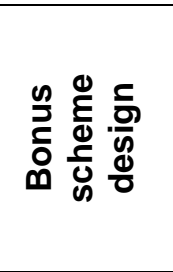 } & SIMPLE & $-0.10178\left(^{*}\right)$ & 0.042594 & SIMPLE & $-0.11195\left(^{\star \star}\right)$ & 0.041858 \\
\hline & PIT & -0.023 & 0.050114 & PIT & 0.046021 & 0.056009 \\
\hline & ET & -0.01709 & 0.076182 & ET & 0.167213 & 0.139683 \\
\hline & UIT & (base) & (base) & UIT & (base) & (base) \\
\hline & Undisclosed & 0.023924 & 0.108638 & Undisclosed & -0.18406 & 0.101119 \\
\hline & $\mathrm{CASH}$ & -0.06612 & 0.045523 & $\mathrm{CASH}$ & $-0.08963\left(^{*}\right)$ & 0.045201 \\
\hline \multirow{5}{*}{ 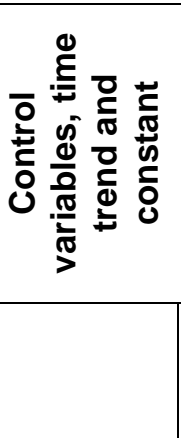 } & American & 0.258619 & 0.181132 & American & $0.32845\left(^{*}\right)$ & 0.16278 \\
\hline & $\begin{array}{l}\text { Other foreign } \\
\text { nationality }\end{array}$ & 0.193321 & 0.108929 & $\begin{array}{l}\text { foreign } \\
\text { nationality }\end{array}$ & $0.207882\left(^{*}\right)$ & 0.086656 \\
\hline & FINANCE & $0.324163\left({ }^{\star \star}\right)$ & 0.10144 & FINANCE & $0.33126\left(^{* *}\right)$ & 0.109236 \\
\hline & Constant & $0.418163(* \star)$ & 0.121335 & Constant & $0.255773\left(^{*}\right)$ & 0.127276 \\
\hline & $\begin{array}{c}\mathrm{N}= \\
\text { F-stat. } \\
\mathrm{R}^{2}\end{array}$ & $\begin{array}{c}257 \\
F(11,245)=6.14 \\
24 \%\end{array}$ & & $\begin{array}{c}\mathrm{N}= \\
\text { F-stat. } \\
\mathrm{R}^{2}\end{array}$ & $\begin{array}{c}257 \\
F(11,245)=4.98 \\
25 \%\end{array}$ & \\
\hline
\end{tabular}


TABLE 5 Number and Types of Bonus Performance Targets (2001-02)

$\begin{array}{rrrrrrr}\text { Performance } & \text { Number of performance targets } & \text { Row } \\ \text { Target Types } & \text { NIA } & \mathbf{1} & \mathbf{2} & \mathbf{3} & \mathbf{4} & \begin{array}{r}\text { total } \\ \text { ET }\end{array} \\ \text { ET \& PIT } & 0 & 0 & 0 & 0 & 0 & \mathbf{0} \\ \text { ET \& PIT \& UIT } & 0 & 0 & 2 & 1 & 0 & \mathbf{3} \\ \text { ET \& UIT } & 0 & 0 & 0 & 4 & 2 & \mathbf{6} \\ \text { PIT } & 0 & 57 & 18 & 7 & 1 & \mathbf{4} \\ \text { PIT \& UIT } & 0 & 0 & 36 & 32 & 12 & \mathbf{8 0} \\ \text { UIT } & 0 & 24 & 37 & 14 & 2 & \mathbf{7 7} \\ \text { Undisclosed } & 22 & 0 & 0 & 0 & 0 & \mathbf{2 2} \\ \text { Column total } & \mathbf{2 2} & \mathbf{8 1} & \mathbf{9 5} & \mathbf{5 9} & \mathbf{1 7} & \mathbf{2 7 4}\end{array}$

